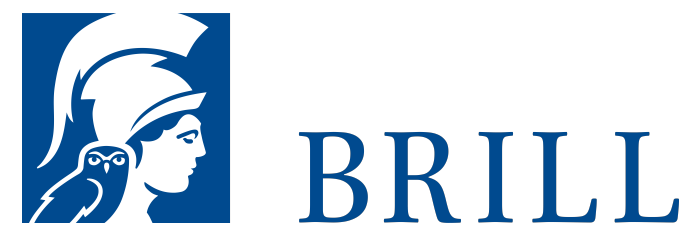

\title{
Hegels Rechtsphilosophie als Metaethik
}

\section{Author: Sebastian Ostritsch}

Wie passt die Moral in die Welt? Ist sie eine bloße Fiktion, Ausdruck individueller Einstellungen, soziales Konstrukt? Oder können wir sagen, dass moralischen Normen und Werten objektive Gültigkeit zukommt und sie unabhängig von individuellem Gutdünken existieren? Dieses Buch unternimmt den Versuch, G. W. F. Hegels Grundlinien der Philosophie des Rechts (1820) für die Beantwortung dieser Grundfragen der Metaethik fruchtbar zu machen. Hierzu wird die aktuelle metaethische Debatte anhand von vier begrifflichen Leitdifferenzen gegliedert. Diese werden dann zur Rekonstruktion von Hegels Rechtsphilosophie eingesetzt. Gezeigt werden soll, dass Hegel über eine komplexe und gegenwärtig nicht vertretene metaethische Theorie verfügt, die scheinbar gegensätzliche Positionen versöhnt: So ist Hegels Rechtsphilosophie zufolge Moral zwar wesentlich an die historische und soziale Selbstbestimmung menschlicher Subjekte gebunden, dadurch aber weder als Projektion noch als Konstrukt noch als Fiktion zu klassifizieren. Vielmehr kommt dieser Selbstbestimmung und damit der Moral objektive Geltung und Existenz zu, insofern sie individueller Willkür und subjektivem Meinen enthoben sind.

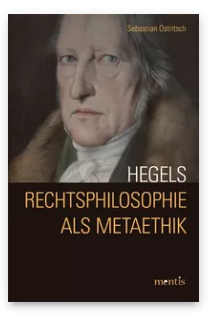

Pages: 370

Seiten

Language:

German

Subjects:

General,

Philosophy

Publisher: Brill | mentis

E-Book (PDF)

Released online: 19 Sep 2014

ISBN: 978-3-

95743-995-6

List price

Paperback

Publication date:

19 Sep 2014

ISBN: 978-3-

89785-230-3

List price 
For more information see brill.com

Order information: Order online at brill.com +44330 333 0049 | customerservices@brill.com Submission information: brill.com/authors

Titles published by Brill | Fink, Brill | mentis or Brill | Schöningh: +49(o)715413279216| brill@brocom.de 